\title{
Case report and immunohistochemical study of a malignant peripheral nerve sheath tumor in a dog
}

\section{Relato de caso e estudo imuno-histoquímico de tumor maligno da bainha do nervo periférico em um cão}

\author{
Thaís de Almeida MOREIRA ${ }^{1}$; Leandro Willian BORGES ${ }^{1}$; Talita Lopes SERRA²; Diego Petrocino CAETANOㄹ; \\ Marcelo Carrijo da COSTA ${ }^{1}$; Alessandra Aparecida MEDEIROS-RONCHI ${ }^{1}$ \\ ${ }^{1}$ Universidade Federal de Uberlândia. Faculdade de Medicina Veterinária, Uberlândia - MG, Brazil \\ ${ }^{2}$ Universidade Federal de Minas Gerais, Faculdade de Medicina Veterinária, Belo Horizonte - MG, Brazil
}

\begin{abstract}
Malignant peripheral nerve sheath tumor is rare and rarely reported in dogs. The term neurofibroma/sarcoma is classically used when the tumor is composed of Schawann and perineural cells. This work describes the clinical, histopathological, and immunohistochemical case of a subcutaneous malignant peripheral nerve sheath tumor, most likely a malignant neurofibroma located in the pelvic member of a Rottweiler dog. Histopathological features and immunohistochemical analysis corroborated the diagnosis, showing positivity for S-100 protein, vimentin, and CD57, and was useful to distinguish this type of neoplasm from other malignancies of similar morphologies.
\end{abstract}

Keywords: Neoplasm. Pelvic member. Canine. Markers.

\section{Resumo}

O tumor maligno da bainha do nervo periférico é raro e pouco descrito em cães. Classicamente, o termo "neurofibroma/ sarcoma" é empregado quando o tumor é composto por células de Schwann e células perineurais. Neste relato são descritos os achados clínicos, histopatológicos e imuno-histoquímicos de um caso de tumor maligno da bainha do nervo periférico, provavelmente neurofibrossarcoma, localizado no subcutâneo do membro pélvico de um cão da raça Rottweiler. Os achados histopatológicos associados às observações imuno-histoquímicas contribuíram para o diagnóstico, sendo observada positividade para proteína S-100, vimentina e CD57, permitindo a diferenciação da neoplasia em questão de outros tumores malignos com características morfológicas similares.

Palavras-chave: Neoplasia. Membro pélvico. Canino. Marcadores.

Correspondence to:

Thaís de Almeida Moreira

Universidade Federal de Uberlândia, Faculdade de

Medicina Veterinária

Av. Mato Grosso, 3289 - Bloco 2S - Umuarama

CEP 38405-314, Uberlândia, MG, Brazil

e-mail: thais-vet@outlook.com

Received: 15/05/2017

Approved: 28/11/2017

Malignant peripheral nerve sheath tumor (MPNST) is rare in dog, with few reports in veterinary medicine literature (SIRRI et al., 2016; HIGGINS et al., 2017) and incidence reported of $0.5 \%$ to $2.0 \%$ of all skin tumors (CAPLAN, 2012). Peripheral nerve sheath tumors (PNST) are a group of mesenchymal neoplasms, and the term schwannoma is used when the tumor cells are exclusively of Schwann-cell origin. The term neurofibroma/sarcoma, on the other hand, is used when the tumor consists of Schwann and perineural cells (HENDRICK, 2017).

The gross morphology of a MPNST includes its firm to soft consistency, well-circumscription and unencapsulated masses in the dermis or subcutis. It usually has white to gray coloration and sometimes slight bulges on the cut surface (PEKMEZCI et al., 2015; HENDRICK, 2017).

The treatment for MPNST is surgical (CAPLAN, 2012). The removal of the tumor and its surrounding tissues may be vital for the patient's survival (PARK et al., 2011; TAVASOLY et al., 2013).

Diagnostic problems can be faced in canine MPNST, due to histopathological similarities with other mesenquimal tumors of fusiform cells (such as hemangiopericytoma, fibrosarcoma, leiomyosarcoma, and myxosarcoma). Thus, 
the use of immunohistochemical markers is necessary for the correct diagnosis, prognosis, and treatment (SUZUKI et al., 2014; PEKMEZCI et al., 2015; SIRRI et al., 2016).

In this way, the aim of this study was to describe the clinical, histopathological, and immunohistochemical case of a MPNST, located in the pelvic member of a Rottweiler dog.

An 8-year-old male Rottweiler dog was submitted to clinical treatment at a veterinary hospital because of an ulcerated subcutaneous mass in its right hind limb. The owner reported that the time of evolution was one year and observed progressive growth. According to the dog's history, it had been under care at a veterinary clinic, in which an excisional biopsy was performed, but a definitive diagnosis had not been established. At this time, the biopsy was suggestive of sarcoma. A previous radiographic examination of the affected limb had already shown that the nodule had no bone involvement. An increase in rod-shaped bacteria was also verified during this period, which was normalized after antibiotic therapy. Other conditions, such as appetite decrease, and digestive or urinary disorders were not noticed.

According to the clinical examination, the nodule measures were $12 \times 8.2 \times 4.5 \mathrm{~cm}$, located in the right hind limb, on the external surface of the medial femoral region. The nodule was subcutaneous and had sharp, regular contour, with firm consistency, small surface ulceration, and low mobility.

Fine needle aspiration cytology (FNAC) was performed, but a lot of blood flowed without flaking tumor cells, making the diagnosis impossible through this method. Hemogram, serum creatinine, and hemoparasitological examination were within normality. A radiographic examination of the affected limb at midlateral and dorsal positions showed that the mass was located in the coxofemoral joint region, extending to the median femoral diaphysis; it had soft tissue compatible with radiopacity and showed no evidence of involvement with adjacent bone structures.

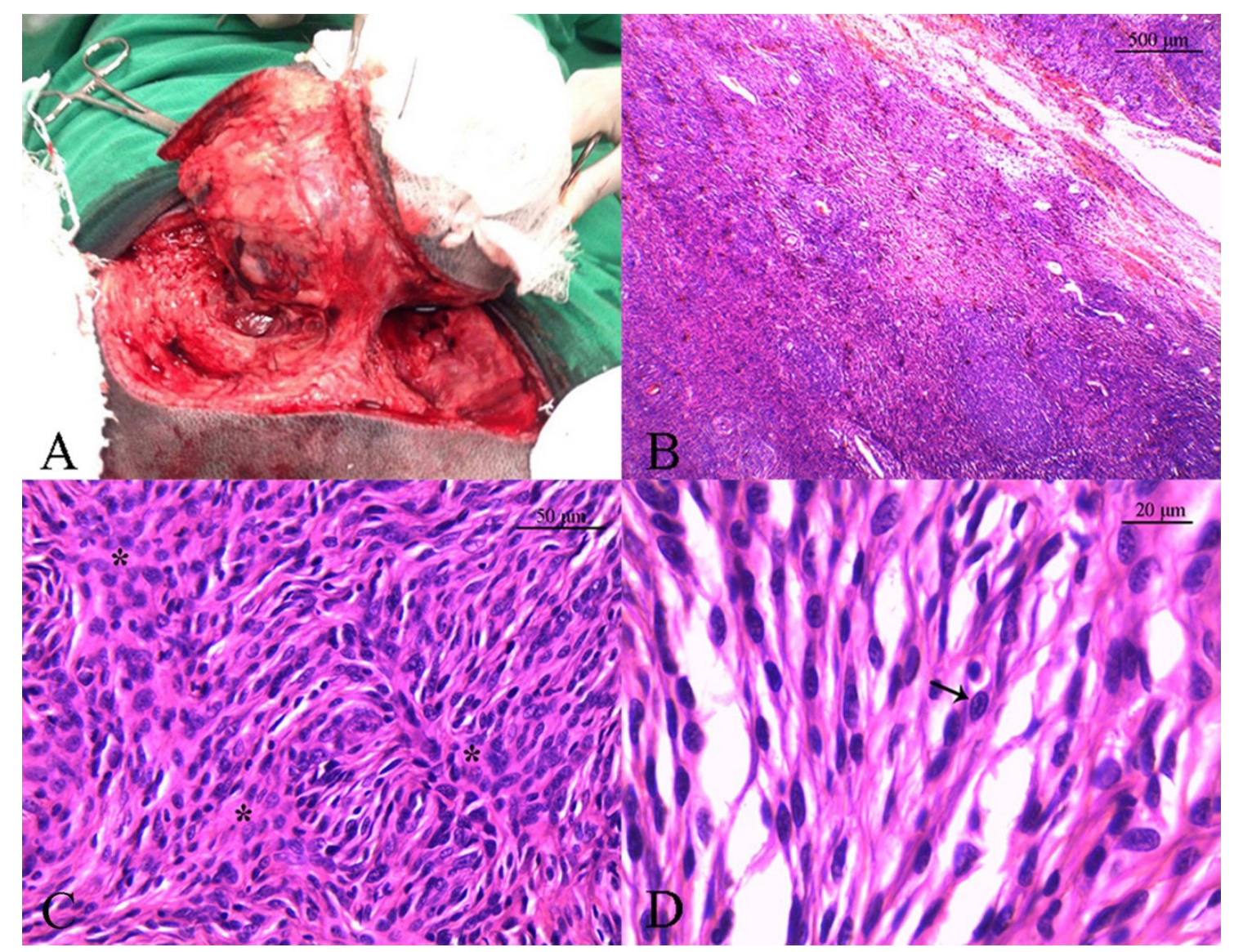

Figure 1 - Macroscopic and microscopic aspect of a MPNST in a Rottweiler dog. A) Intraoperative period. Rounded, regularly contoured and well-vascularized mass, denoting adherence to the musculature (shape). B) The tumoral mass was composed of neoplastic cells arranged in a storiform pattern, with many red blood cells. HE staining, 4x. C) Neoplastic spindle cells presented high pleomorphism, hyperchromatic, larger, tapered nuclei, marked nuclear atypia, and scant eosinophilic cytoplasm. Hypocellular myxoid areas of mucinous matrix and cellular necrosis focus is observed $(*)$. HE staining, 40x. D) Some neoplastic cells presented multiple nuclei and mitotic figure (shape). HE staining, 100x 
Tissue sections, processed routinely for histopathology, embedded in paraffin, were placed on previously silanized slides. Antigenic recovery by the moist heat method was carried out in a steamer for 20-30 min. Primary antibodies incubation was performed by overnight at $4^{\circ} \mathrm{C}$. The Advance system was used for revelation. Staining was performed with 3.3 diaminobenzidine and counterstained with hematoxylin. External and/or internal controls were used to validate the reaction.

The antibodies immunohistochemically tested were vimentin (V9, Dako, 1:100), anti-S100 protein (Z0311, Dako, 1:800), CD57 (TB01, Dako, 1:100), desmin (D33, Dako, 1:100), glial fibrillary acidic protein (GFAP - Z0334, Dako, 1:3000), muscle-specific actin (HHF35, Dako, 1:1000), alpha smooth muscle actin (1A4, Dako, 1:250), and MyoD1 (5.8A, Dako, M3512, 1:140).

Positive marking was found in about $80 \%$ of the cells for vimentin (marker of filaments of mesodermal origin), S-100 protein (marker of neural crest cells), and CD57 (reactivity in neural lineage cells) (Figure 2). Desmin, GFAP, HHF35, 1A4, and MyoD1 showed no immunoreactivity. Thus, the diagnosis of MPNST grade 2 , most likely a malignant neurofibroma, was concluded based on the histopathological and immunohistochemical findings, as observed by Hagen et al. (2015). The dog was followed clinically and presented satisfactory postoperative recovery. Until the present moment (15 months after the surgical treatment) the dog's condition had not recurred and it walked normally.

MPNST include malignant schwannoma and malignant neurofibroma (or neurofibrosarcoma) (CAPLAN, 2012; PEKMEZCI et al., 2015). In human medicine, this distinction can be made by immunohistochemical analysis with S100, GFAP, or other specific neural markers (CUNHA et al., 2012; LIU et al., 2013; ANITHAKUMARI et al., 2015). On the other hand, in veterinary medicine these entities are under the title MPNST, because several diagnoses are made without these ancillary test markers and are nonspecific or overlap in specificity in animal species (HENDRICK, 2017). Nevertheless, the malignant neurofibroma classification is referred by Tavasoly et al. (2013) and Hagen et al. (2015) in canine MPNST cases.

Differential diagnosis would need to include other spindle cell-like sarcomas, such as malignant schwannoma, fibrosarcoma, leiomyosarcoma, and perivascular wall tumors (hemangiopericytoma). The intertwined spindle cells microscopically observed in

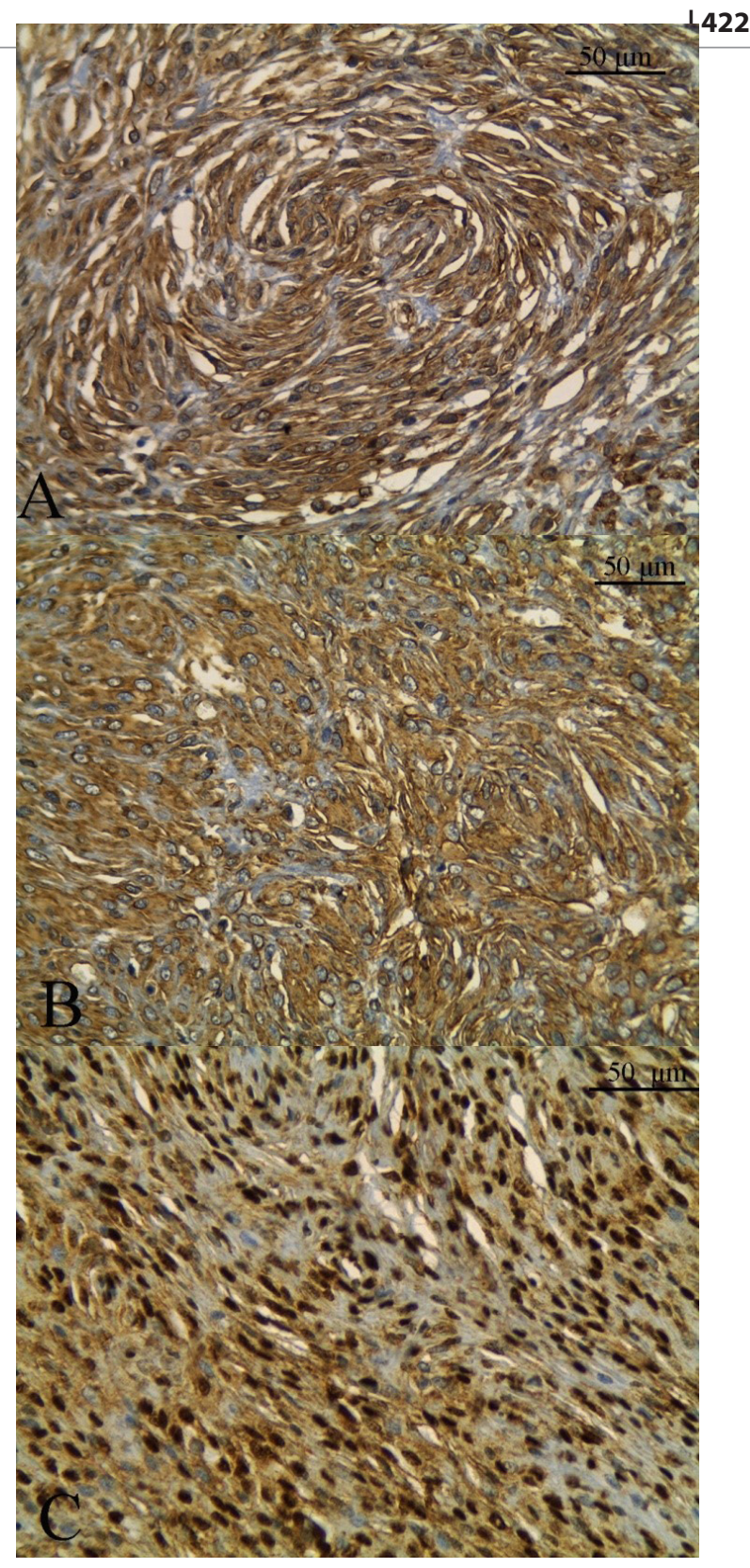

Figure 2 - Immunohistochemical staining of a MPNST. Strong reactivity (about in $80 \%$ of the cells) for: A) Vimentin with cytoplasmic positivity in tumor cells (streptavidin-perosidase, SP, hematoxylin counterstaining $\times 200$ ); B) S100 protein, denoting tumor cells with cytoplasmic and matrix positivity (streptavidin-perosidase, SP, hematoxylin counterstaining $\times 200$ ); and C) CD57 with cytoplasmic positivity (streptavidin-perosidase, SP, hematoxylin counterstaining $\times 200$ )

the present study were arranged in a storiform pattern, with elongated nuclei, high pleomorphism and many mitoses. These cells were similar to those observed by Hagen et al. (2015) in a case of MPNST, which was most likely a neurofibrosarcoma. Considering these results, distinguishing MPNST is important, and evaluating the expression of several markers is necessary for diagnosis and prognosis of neoplasms (SUZUKI et al., 2014; SIRRI et al., 2016; HIGGINS et al., 2017). 
The immunohistochemical analysis of the present case showed positivity for S-100 protein and vimentin, which was also observed by Tavasoly et al. (2013) and Hagen et al. (2015), defining the diagnosis. Thus, among the differential diagnoses cited by literature (SUZUKI et al., 2014; BARATT et al., 2015), the fibrosarcoma diagnosis was excluded in the present case, since fibrosarcomas are negatives for S-100 protein, as reviewed by Higgins et al. (2017). The hemangiopericytoma and leiomyosarcoma diagnoses were also excluded, since they present reactivity to desmin, HHF35, 1A4, and MyoD1 (CUNHA et al., 2012; SUSUKI et al., 2014; SIRRI et al., 2016), which was not seen in the present case. Moreover, schwannomas are positive for glial fibrillary acidic protein (GFAP), an intermediate astrocyte filament (MARLO et al., 2017), and in the present work, as in the evaluation of Hagen et al. (2015), the GFAP was negative.

The macroscopic aspect of the MPNST found was similar to that described in other scientific papers, which reported the subcutaneous location of this tumor (TAVASOLY et al., 2013). Nevertheless, uncommon location is reported by Baratt et al. (2015), in a case of lingual MPNST in a Chinese Pug Dog presenting smooth, glossy, and non-ulcerated surface.

\section{References}

ANDREW, S. E. Orbital neurofibrosarcoma in a dog. Veterinary Ophthalmology, v. 2, n. 3, p. 141-145, 1999. doi: 10.1046/j.1463-5224.1999.00078.x.

ANITHAKUMARI, A. M.; SOMASHEKHAR, S. P.; MONDAL, S. K. Neurofibrosarcoma of the Subglottis - A Rare Case Report. Indian Journal Surgery Oncology, v. 6, n. 2, p. 113-115, 2014. doi: 10.1007/s13193-014-0364-x.

BARATT, R. M.; RAWLINSON, J.; ROTH-JOHNSON, L.; JONES, C. J. Lingual Malignant Peripheral Nerve Sheath TumorinaChinesePugDog.Journal of Veterinary Dentistry, v. 32, n. 3, p. 165-172, 2015. doi: 10.1177/089875641503200303.

CAPLAN, E. R. Nervous system. In: SIMON, T. K.; SÉGUIN, B. (Eds). Veterinary surgical oncology. 3. ed. Iowa: WileyBlackwell, 2012, p. 465-490.

CUNHA, K. S. G.; CARUSO, A. C.; FARIA, P. A. S.; SILVA, L. E.; PIRES, A. R. C.; GELLER, M.; LOPES, V.
The one-year evolution time reported in the present case is longer than in other cases in the literature for canine MPNST, which reported evolution times lower than six months (ANDREW, 1999; BARATT et al., 2015; GIBSON et al., 2016). No metastasis was observed in the present case, which is consistent with the literature, since less than $20 \%$ of the cases metastasize (CAPLAN, 2012). Nevertheless, despite the high rate of recurrence reported for this type of tumor (CAPLAN, 2012; HIGGINS et al., 2017), it was not observed in the present case.

The result of the previous cytopathology, which was performed in the present study, often does not coincide with the diagnosis (ANDREW, 1999), however, it is important for the exclusion of diagnosis of other cutaneous neoplasms that have non-surgical treatment, such as transmissible venereal tumor (HIGGINS et al., 2017).

The diagnosis of MPNST is difficult, thus descriptions about the tumor, as presented here, are important. Differing from other reports, in this case the prognosis was favorable and the dog had a good recovery, without recurrences. Moreover, immunohistochemistry was fundamental for the diagnostic conclusion, and it must be considered in similar cases of cutaneous tumors.

S.; MOURA-NETO, R. S. Malignant peripheral nerve sheath tumors: clinicopathological aspects, expression of p53 and survival. Clinics, v. 67, n. 8, p. 963-968, 2012. doi: 10.6061/clinics/2012(08)18.

GIBSON, A. D.; DAVIES, E.; LARA-GARCIA, A.; LAFUENTE, P. Palliative epineurotomy for focal radial malignant peripheral nerve sheath tumor in a dog. Journal of American Animal Hospital Association, v. 52, p. 330-334, 2016. doi: 10.5326/JAAHA-MS-6336.

HAGEN, F.; ROMKES, G.; KERSHAW, O.; EULE, J. C.; Malignant peripheral nerve sheath tumor of the third eyelid in a 3-year-old Rhodesian Ridgeback. Clinical Case Reports, v. 3, n. 1, p. 50-56, 2014. doi: 10.1002/ccr3.146.

HIGGINS, R. J.; BOLLEN, A. W.; DICKINSON, P. J.; SISÓLLONCH, S. Tumors of the nervous system. In: MEUTEN, D. J. Tumors in domestic animals. 5. ed. Ames, Iowa: John Wiley \& Sons Inc., 2017. p. 888-889. 
HENDRICK, M. J. Mesenchymal tumors of the skin and soft tissues. In: MEUTEN, D. J. Tumors in domestic animals. 5. ed. Ames, Iowa: John Wiley \& Sons Inc., 2017. p. 142-175.

LIU, X.; TANG, K.; SUI, L.; XU, G. Neurofibrosarcoma of the gallbladder: a case report. World Journal of Surgical Oncology, v. 11, n. 1, p. 189, 2013. doi: 10.1186/1477-7819-11-189.

MARLO, T. L.; GIULIANO, E. A.; MOORE, C. P.; SHAW, G. C.; TEIXEIRA, L. B. C. Uveal schwannoma in a brown-eyed dog. Veterinary Ophthalmology, p. 1-5, 2017. doi: 10.1111/vop.12458.

PARK, J. W.; WHO, G. H.; JEE, H.; JUNG, D. W.; YOUN, H. W.; CHOI, M. C.; KIM, D. Y. Malignant Peripheral Nerve Sheath Tumour in the liver of a dog. Journal of Comparative Pathology, v. 144, n. 2, p. 223-226, 2011. doi: 10.1016/j.jcpa.2010.08.009.

PEKMEZCI, M. REUSS, D. E.; HIRBE, A. C.; DAHIYA, S.; GUTMANN, D. H.; DEIMLING, A.; HORVAI, A. E.; PERRY, A. Morphologic and immunohistochemical features of malignant peripheral nerve sheath tumors and cellular schwannomas. Modern Pathology, v. 28, p. 187-200, 2015. doi: 10.1038/modpathol.2014.109.

SIRRI, R.; SABATTINI, S.; BETTINI, G.; MANDRIOLI, L. Reclassification of 21 presumptive canine peripheral nerve sheath tumors (PNST) using a literature-based immunohistochemical panel. Acta Veterinaria-Beograd, v. 66, n. 4, p. 455-465, 2016. doi: 10.1515/acve-2016-0039.

SUZUKI, S.; UCHIDA, K.; NAKAYAMA, H. The effects of tumor location on diagnostic criteria for canine malignant peripheral nerve sheath tumors (MPNSTs) and the markers for distinction between canine MPNSTS and canine perivascular wall tumors. Veterinary Pathology, v. 51, n. 4, p. 722-736, 2014. doi: 10.1177/0300985813501336.

TAVASOLY, A.; JAVANBAKHT, J.; KHAKI, F.; HOSSEINI, E.; BAHRAMI, A.; HASSAN, M. A.; MIRABAD, M. Ulnar malignant peripheral nerve sheath tumour diagnosis in a mixed-breed dog as a model to study human: histologic, immunohistochemical, and clinicopathologic study. Diagnostic Pathology, v. 8, n. 86, p. 1-6, 2013. doi: 10.1186/1746-1596-8-86. 